\title{
Japan's New National Library
}

Dr. Downs is director, University of $\mathrm{Il}$ linois Library and Library School.

$I_{\text {Novernment following the war, the na- }}^{\text {N The }}$ tional legislative body, the Diet, was given powers somewhat comparable to our own Congress. ${ }^{1}$ Previously, under the old regime, the Diet had been little more than a debating society and rubber stamp. When the change came in 1946, members of the body felt the need for a strong, modern research library, and especially for legislative reference service. Their eyes naturally turned to the United States Library of Congress as a model for the national library they wanted to see established in Japan. The chief officers of the Diet therefore requested General MacArthur to invite American experts to visit the country to advise them in planning the library. In response to this request and on invitation of the Supreme Commander of the Allied Powers, Charles H. Brown of Iowa State College and Verner W. Clapp of the $\mathrm{Li}$ brary of Congress went to Japan in December 1947. While there, from December to February 1948, Mr. Brown and Mr. Clapp helped to draft and get through the Diet, legislation setting up the National Diet Library.

Some indication of the high hopes held by the Diet members is given in a speech with which the chairman of the library committee of the House of Representatives, Kazu Nakamura, introduced the National Diet Library bill:

1 The Diet's organization resembles more closely the British Parliament than it does the Congress of the United States. Cabinet members have seats in the Diet and the system of elections is based more on the English than the American.
I expect very much from the projected $\mathrm{Li}$ brary, and think that all my colleagues here will probably agree with me on this point. In both public and private offices in Japan things are not kept in good order, so it is not easy to get documents and other materials from these offices without previous notice, in striking contrast to parliamentary or public libraries in the United States and other advanced countries where all things are kept in excellent order and any books wanted can be got at a notice of say 5 to 10 minutes. What we feel most regrettable in this connection is that when we visit a government office wishing to see some documents previously presented to it, it is not rare we have to wait for half a day, or are told to come again later, simply because these documents were somehow misplaced and cannot be found at once by the clerk in charge. In foreign countries, where things are kept in neat order, people would never have such unpleasant experience, and they can work efficiently. The same thing can be said of housekeeping. In America and Europe, kitchen, sweeping and all other work are mechanized and housewives can keep their homes in order without spending so many hours as their Japanese sisters are being obliged to spend. Compared with the condition in this country, theirs in the west is indeed to be envied.

With this rosy, and somewhat idealized picture before it, the representative passed unanimously, on Feb. 4, 1948, the bill to create a national library for Japan. On the same day and about one hour later, Chairman Goro Hani of the library committee of the House of Councillors introduced the bill in that body where it was likewise passed immediately and without a dissenting vote. The library was formally opened about two months later, occupying the Akasaka Palace in Tokyo.

The Akasaka Palace, selected as the 
temporary home of the new library, was completed in 1909 at an expenditure of I5,000,000 yen (the equivalent then of about $\$ 7,500,000)$. Intended to accommodate royal visitors to Japan, the building is an excellent imitation of the Versailles Palace in France, and its appearance is far more European than Japanese. Even the marble and interior decorations were imported from Italy, France and Egypt. For most of its existence, the Akasaka Palace has remained closed, because of the expense of heating and lighting. Whatever its other virtues, the palace has serious defects for library purposes. It is remote from the Diet building and consequently few members come to use it. Another drawback is its limited space for books, an impediment to development of a large collection. Plans are being drawn for construction of a library building adjacent to the Diet, on a site formerly occupied by the General Military Staff, but building materials are even scarcer in Japan than in America, and some years are likely to elapse before a new national library building is a reality.

The present writer's mission to Japan, from June to September 1948, was concerned principally with the internal organization of the National Diet Library. Problems were numerous: Where could suitable personnel be recruited for the library? What system of classification should it adopt? Should roman letters or Japanese characters be used in catalogs? Should the library set up a centralized cataloging service for other libraries, similar to that of the Library of Congress in the United States? What should be done about other libraries in the government system? Should a national union catalog be established? What should be done about copyright legislation, publication of a national bibliography and international exchanges?

In all recommendations concerning these and related questions, every effort was made to build upon what has already been accomplished by Japanese librarians, rather than trying to impose unfamiliar American methods on them. For a long period the Japanese have shown an active interest in the technical phases of librarianship and have made useful contributions in the field, particularly for oriental literature. Whenever possible, therefore, it was suggested that the National Diet Library adopt procedures already known to Japanese libraries -revising and expanding these methods if necessary or desirable.

\section{Personnel}

One of the major problems faced by the National Diet Library is finding a competent staff. In fact the most serious weaknesses of librarianship in Japan are the scarcity of librarians with professional training and the lack of training agencies. The Ueno Library School, started in Tokyo in I92 I, under the Ministry of Education, was the only library school in the entire country before 1948. The Ueno School has no college or university connection, until recently required only high school graduation for admission, and its enrolments were always small. Because of this situation, the National Diet Library could not hope to find enough professionally trained librarians to fill more than a limited number of positions. Even persons with satisfactory experience in libraries are few. In all Japan, it is reported, there are only four Japanese librarians trained in American schools, a very low figure compared, for example, to China, which has sent many library school students to the United States.

Several steps are being taken to solve the personnel dilemma. An in-service training program has been organized in the National Diet Library to give basic training to staff members there. New library schools are 
getting under way at Tokyo University and Kyoto University, the two Japanese universities with greatest prestige and best facilities. In addition, as soon as financial arrangements can be made, a number of good prospects may be sent to the United States for training.

Chiefly because of their poor preparation in the past, librarians rank low among professional groups in Japan, a condition that will not change until the level of professional training is raised. The slight esteem in which librarians are held is reflected in the miserable salary scales. With the inflationary prices now prevailing in Japan, mere survival on salaries being paid is next to impossible.

\section{Technical Problems}

The first important technical decision to be made in the National Diet Library was whether oriental and occidental books were to be treated alike in all respects. That is, should the two categories be shelved together, classified by the same system, catalog cards be interfiled, and otherwise administered without regard to language differences. On the basis of the experience of American libraries holding major oriental collections, it was concluded that the two groups of books should preferably be kept separate. Otherwise the language problem is extremely complicated. Japanese libraries that have tried to merge books in all languages have come out with hodgepodge arrangements. Accordingly, it was agreed in the National Diet Library that oriental books should be shelved apart from those in European languages, different classification and cataloging plans followed, and separate catalogs maintained.

\section{Classification}

Of all phases of librarianship, the Japanese appear most devoted to classification.
A difficulty arises, however, in that no one is willing to accept anybody else's classification. Nearly every library has its own system, usually designed by the librarian. Many schemes are variations of Dewey, at least to the extent of preserving the decimal principle, but for the most part they have simply used Dewey as a point of departure and then departed as far as possible. The only classification that has won anything like general acceptance is the "Nippon Decimal Classification," first published 20 years ago, now in its fifth edition, and used by perhaps io per cent of Japanese libraries.

After careful consideration of various factors, it was recommended that the $\mathrm{Na}$ tional Diet Library adopt the Nippon Decimal Classification for its Japanese-Chinese books and the Dewey Decimal Classification for books in European alphabets. Being planned for oriental literature, the "NDC" makes more adequate provision for Japanese and Chinese books than does either the Dewey or Library of Congress systems. On the other hand, the NDC would not be suitable for western books, because it has no place for many important categories of occidental literature. The proportion of oriental books in the National Diet Library will always be considerably larger than western books, and the unabridged Dewey classification will be adequate for the EuropeanAmerican section for an indefinite period. The greater detail and expandability of the Library of Congress plan are unnecessary.

\section{Cataloging}

Second only to their interest in classification is the Japanese librarians' liking for cataloging. A similar lack of uniformity prevails in this area. One of the much debated questions is whether to use authors or titles for main entries. For books prior to the Meiji period, about I868, it is often difficult to discover an author's name, and 
the title may be the only means of identification. The problem is met with less frequently in modern books. Nevertheless, main entries under titles persist in a considerable percentage of Japanese libraries, especially in older institutions. From an historical point of view, the practice may be traceable to a failure in the oriental world to recognize what one writer has called "the concept of individual personality," which means in this case that the book is everything and the writer nothing. The process of democratization in Japan would doubtless be aided by greater consciousness of individuality and library catalogs can contribute, even though in a minor way, to such awareness. It was therefore agreed that the National Diet Library should have main entries under authors.

Another important decision was whether to use roman letters or Japanese characters in catalogs for oriental books. The romanized form of Japanese is being taught to millions of children in the elementary schools, and is widely used in progressive Japanese libraries. Future library readers will be familiar with the alphabet and should experience no difficulty in using catalogs in which authors' names, book titles, and subject headings are in Romaji form. Among the advantages are convenience in filing, ready finding of information from catalogs, and facilitating international exchange of cards. Romaji will be used by the National Diet Library in its catalogs of oriental literature, and in addition, of course, the original Japanese or Chinese characters will be shown. The exact method of romanizing, however, e.g., Hepburn or Kunreishiki for Japanese, or Wade-Giles for Japanese, has not yet been determined and is in process of study.

The multiplicity of catalogs in some Japanese libraries is bewildering. In contrast to a typical American library, with its single dictionary catalog, it is not unusual to find six or more files in a Japanese library. Tokyo University Library, for example, has three separate catalogs for western books (author catalog, classified catalog for books in the main library and classified catalog for books in the departmental libraries), and four catalogs for oriental books (author catalog, classified catalog, author catalog for departmental libraries and title catalog for departmental libraries). Even librarians became lost in the maze, and one can only imagine the readers' state of confusion. For the National Diet Library, it was decided to reduce this labyrinth of files to two -a dictionary catalog for oriental books and a dictionary catalog for western books. This step is little short of revolutionary for a Japanese library.

It is expected that the National Diet Library will begin soon issuing printed cards for oriental books, and making these cards available to other Japanese and foreign libraries. The cards should do much to standardize cataloging and classification practices among Japanese libraries, and will also benefit libraries abroad engaged in acquiring Oriental collections.

\section{National Union Catalog}

For some years the possibility of a national union catalog for Japanese libraries has been under consideration. Such an undertaking would have great value for making the country's library resources more generally available. There are several union lists of periodicals in Japan, but practically nothing else to help locate research materials. It is generally agreed among Japanese librarians that the National Diet Library is the logical home for the union catalog, as is the Library of Congress for libraries in the United States. At the beginning, according to the program worked out, libraries in various government bureaus 
and departments are to be included. Then will come the Universities and certain prefectural and research libraries. Eventually the union catalog will record the holdings of approximately 400 institutions having significant research materials.

For insurance purposes, and to spread its usefulness, a duplicate file of the national union catalog may be set up in Kyoto, the second principal library center of the country, some 400 miles from Tokyo.

\section{Bibliographical Publications}

The lack of adequate national bibliographical publications in Japan is conspicuous. There has been nothing, for example, to correspond to the Cumulative Book Index in the United States, or the English Catalogue of Books for Great Britain. A recommendation was made that a Japanese national bibliography, recording all publications originating in Japan, be issued by the National Diet Library. Such a publication has now been started on a monthly basis, with plans to cumulate into annual volumes. It is likely that a current index to Japanese periodicals will also be launched in the near future. A card index has been in preparation for several months in the Periodical Division of the Diet $\mathrm{Li}$ brary.

\section{Copyright}

In most countries with national libraries, it is the practice to require publishers to deposit copies of copyrighted books. Such a provision has helped to maintain the steady and automatic growth of the Library of Congress, British Museum, Bibliothèque Nationale, and other national libraries.

The present copyright situation in Japan is in a state of considerable confusion. During and preceding the war, copyright was administered by the Home Ministry, which used it as an instrument of strict censorship. After the Japanese surrender, the Home
Ministry was one of the agencies completely banned by the Military Government, because of its notorious record. According to the prevailing law, the Ministry of Education is charged with registration of copyright, but no deposit of copies is required. In any case, under Japanese law, copyright is automatic as soon as an author completes his manuscript, with or without registration, and is in effect for the author's lifetime plus 30 years.

The law setting up the National Diet Library stipulates that publishers are to deposit copies of copyrighted books in the library, though no penalties are imposed for failure to make such deposits. It is, therefore, a voluntary matter on the part of publishers. Quite understandably, the publishers like their present freedom, and are not anxious to return to anything like the rules which prevailed under the old Home Ministry. On the other hand it is doubtful whether the National Diet Library is receiving, through the voluntary plan, as much as 50 per cent of Japanese copyrighted books. Obviously, a true national library should be a complete depository for all copyrighted books. Otherwise, its growth will be retarded, and it can never become a comprehensive center for bibliographical information concerning books issued in the country. The National Diet Library's projects for publication of a current Japanese bibliography, printing of catalog cards, and compilation of a union catalog can be only partially successful unless the library has access to the entire output of the country's publishing industry.

Several possible solutions to the copyright situation are under consideration. One is for the Paper Allotment Office, in charge of paper rationing, to require that copies of books for which paper is granted are to be deposited in the Diet Library. This agency, however, is temporary, and 
presumably will be abolished when the present paper shortage ends. Another possibility is to transfer registration of copyright from the Ministry of Education to the National Diet Library, which would have a more direct interest in obtaining deposit of all copyrighted material. Incidentally, the whole problem of copyright deposit in Japan is complicated by the present extensive black market in paper. Many books are issued without registration and without the knowledge of the Ministry of Education or the Paper Allotment Office.

\section{International Exchanges}

Another field of importance to the $\mathrm{Na}$ tional Diet Library in building up its collections is international exchanges. This is recognized by the National Diet Library law, which specifies that the library is to receive 50 copies of every publication issued by a governmental agency, to be used for foreign exchange and other official purposes. Since its establishment, the library has been accumulating the number of documents indicated but is just beginning to enter into exchange relationships with other institutions and governments. Eventually the library expects to exchange documents with the principal countries of the world, in the same way that the Library of Congress uses United States documents.

An acute problem confronting the $\mathrm{Na}$ tional Diet Library and all other Japanese libraries is how to acquire American and European books. The lack of books from the western world for the past ro years is almost complete. The Japanese yen cannot be used for international financial transactions, and therefore has no value for the purchase of books outside Japan, even if library budgets were not infinitesimally small. Virtually the only means by which foreign books can be acquired is through international exchanges, now officially authorized, or through gifts. This is a situa- tion of fundamental importance to Japanese scholars, research workers and students, who in the past have depended heavily upon books from occidental countries.

\section{Public Services}

The National Diet Library's primary function is legislative reference service, and the Research and Legislative Reference Department is quite properly the strongest division of the organization. In its professional staff of 24 are subject specialists in law, political science, industry, transportation, communications, public finance, education, labor and statistics, and other fields are being added. The department is charged with providing assistance in bill drafting, with preparation of an index to Japanese law, and with publication of legislative journals. Because of the distance between the National Library and the Diet, and to bring about more effective liaison with Diet members, a branch of the department has been established in the Diet Building. Much depends upon the work of this department, for no great national library for Japan can be developed without wholehearted support from the Diet. The Diet Library must justify its existence by proving that it can make a major contribution to governmental efficiency. Otherwise it will be unable to win adequate backing from the appropriating body, and its activities and growth will be constantly hampered.

In its general public service relationships, the Diet Library has encountered several problems. One is the question of providing library facilities for children. When the library was first opened, it was not the intention to admit children. For several reasons, however, the policy was changed. It was found that adult patronage at the beginning was less than expected, and children's books and periodicals deposited by the publishers were not being used. Fur- 
ther, there was a belief that the indifference to, or lack of knowledge of, library service among a majority of parents might be corrected through work with their children. As public libraries are lacking or limited for Tokyo residents generally, there was little danger of duplicating the work of other agencies. These considerations led to the opening of a special reading room for children in the Diet Library. From the standpoint of use, there is no question that establishment of a children's division was fully justified. Space assigned was crowded at all hours. A difficulty arose, however, when the children started swarming all over the building, to the considerable annoyance of everyone else. It was also questionable whether the admission of children was a sound plan from the point of view of an institution aiming to become a great reference and research library, rather than a popular public library. In the case of the Diet Library, it was decided to continue providing library facilities for children until some other agency is organized to take over the responsibility, but a separate building entrance was arranged in order to make it unnecessary for children to go into adult divisions, and children are limited to the use of the area set aside for them.

Another reading room problem is caused by high school and college students who bring their own books and simply use the library reading rooms as places to study. This seems to be a Japanese custom, as few students have satisfactory conditions for work at home. In the long run, though, because of the pressure on reading room space, this type of use will have to be eliminated and a rule established that only library materials may be read in the library. Large American libraries, e.g., the New York Public Library, have found it necessary to enforce such a regulation to save space for readers who come to use library books.

\section{Other Government Libraries}

Before establishment of the National Diet Library, a system of government libraries had grown up in Japan. Under the law, these libraries are to be regarded as branches of the new national library. Largest and probably oldest is the Ueno Park Library, founded in 1872 , under the Ministry of Education. The Ueno Library's collections are general in character and total more than $1,000,000$ volumes. A merger with the National Diet Library has been proposed, but space limitations at present make that plan impracticable. The long-range program, however, is to transfer from the Ueno Library's holdings all books needed by the Diet Library, leaving the remaining books and the Ueno building to become the Tokyo Public Library. The Ueno collection will form an excellent foundation for the new national library, especially in oriental fields.

Libraries developed by other ministries, bureaus and divisions of the Japanese government likewise contain a considerable wealth of resources for research. Outstanding for their coverage of special fields are the libraries of the Law Institute (Attorney General's Office), Patent Office, Statistics Bureau, Transportation Ministry, Finance Ministry, Communications Ministry and Ministry of Foreign Affairs. More general in nature and notable for rare books and manuscripts are the Imperial Palace Library and the Imperial Cabinet Library.

In the future growth and development of the National Diet Library it is important, of course, to take into account the facilities of these special libraries. The general policy recommended to and accepted by government leaders is to have the Diet Library become a general research library, covering divisons of knowledge not represented in the branch libraries and avoiding (Continued on page $4 I 6$ ) 
specialist in a subject field. Such periodicals therefore must be indexed for both types of users, and this is done by including them in the general index such as Readers' Guide and also in the appropriate special indexAgriculture Index, Education Index or another. Librarians in larger libraries reported that the indexes were often housed far apart-the special ones in the special libraries and the general ones in the main reading room. The specialist was averse to going to another part of the building for the general material related to his field included in the general index. On the other hand, the general reader had difficulty finding the articles on a special subject in the physically remote and more intricately divided special subject index. The Wilson Company at the time this statement was made objected to the term "duplication" preferring "overlapping" as the more accurate.

The difference between the problems presented by duplication or overlapping of publication and duplication of preparation must be kept in mind at all times. There is little data to contradict the conclusion reached by a special conference on scientific abstracting convened by ASLIB in I93I that overlapping in publication "may be unavoidable in practice, and, indeed, may well be an essential factor in the provision of efficient services." ${ }^{23}$ The same group thought that the overlapping in preparation, might, in some cases, be eliminated almost entirely by collaboration in the examination of the literature and in the preparation, and even checking and editing, of the abstracts themselves.

\section{I950 Conference}

The group has not developed in detail recommendations as to the nature and purposes of meetings and conferences which might be held in 1950 to discuss world bibliographical problems.

\footnotetext{
23 Eldridge, A. A. "Scientific and Technical Abstract. ing: A Report on the ASLTB Enquiry." In Associa. tion of Special Libraries and Information Bureaux. Report of Proceedings . . Ninth Conference... 1932. London, 1932 , p. 86.
}

\section{Japan's New National Library}

\section{(Continued from page 387)}

wholesale duplication of collections already available in the government system. At the same time the branch libraries will continue to be built around their specialized subject interests and will not attempt to acquire general or unrelated collections. Other recommendations, some of which are now being put into effect, were to make cataloging and classification practices in departmental libraries uniform with those of the Diet Library; to study the possibilities of centralized cataloging; to prepare a union catalog of the holdings of departmental libraries; and to make books freely available on interlibrary loans among the libraries in the government organization. If these policies are followed through,
Japan will eventually have a system of government libraries similar to that of our own federal government in Washington.

\section{Conclusion}

After working with the Japanese for several months, one could not avoid a feeling of considerable optimism about the future of the National Diet Library. There is a widespread desire and determination among the Japanese themselves to have it succeed, and much interest in it among Military Government officials. Given reasonably favorable conditions during the next generation or two the Diet Library should become one of the important national libraries of the world. 